\title{
Penguasaan Mufradat Bahasa Arab Yaumiyyah Siswa TPQ Nurul Iman Pati
}

\author{
Aizzatul Laili \\ Institut Pesantren Mathaliul Falah Pati \\ aizzawa91@gmail.com \\ Furaida Ayu Musyrifa \\ Universitas Islam Negeri Maulana Malik Ibrahim Malang \\ Furaida28@gmail.com \\ Khabibi Muhammad Luthfi \\ Universitas Sebelas Maret Surakarta \\ habibi.abeb@staff.uns.ac.id
}

\begin{abstract}
This paper aims to determine the student's daily lexical mastery of Koran Education School (TPQ) Nurul Iman Pati in Central Java. This departs from the uniqueness of this TPQ which combines lexical learning of the Qur'an with everyday vocabulary in gradation into nine levels. The approach to this research is quantilative, which sources data from the field and students by collecting data through tests, interviews, observation and documentation. The data analysis uses the percentage technique and the Spradley Model with the technique of domain, taxonomy, components and cultural themes of conclusion. The results showed that TPQ students' mastery of everyday vocabulary in the form of hierarchical semantics, feature comparisons and the spreading activation network was very good and the factors that influenced it were competence or language potential, age, and first language of the students; learning materials and their use in the real world; and educators.
\end{abstract}

Keywords: mastery, lexical, daily life, learning material. 


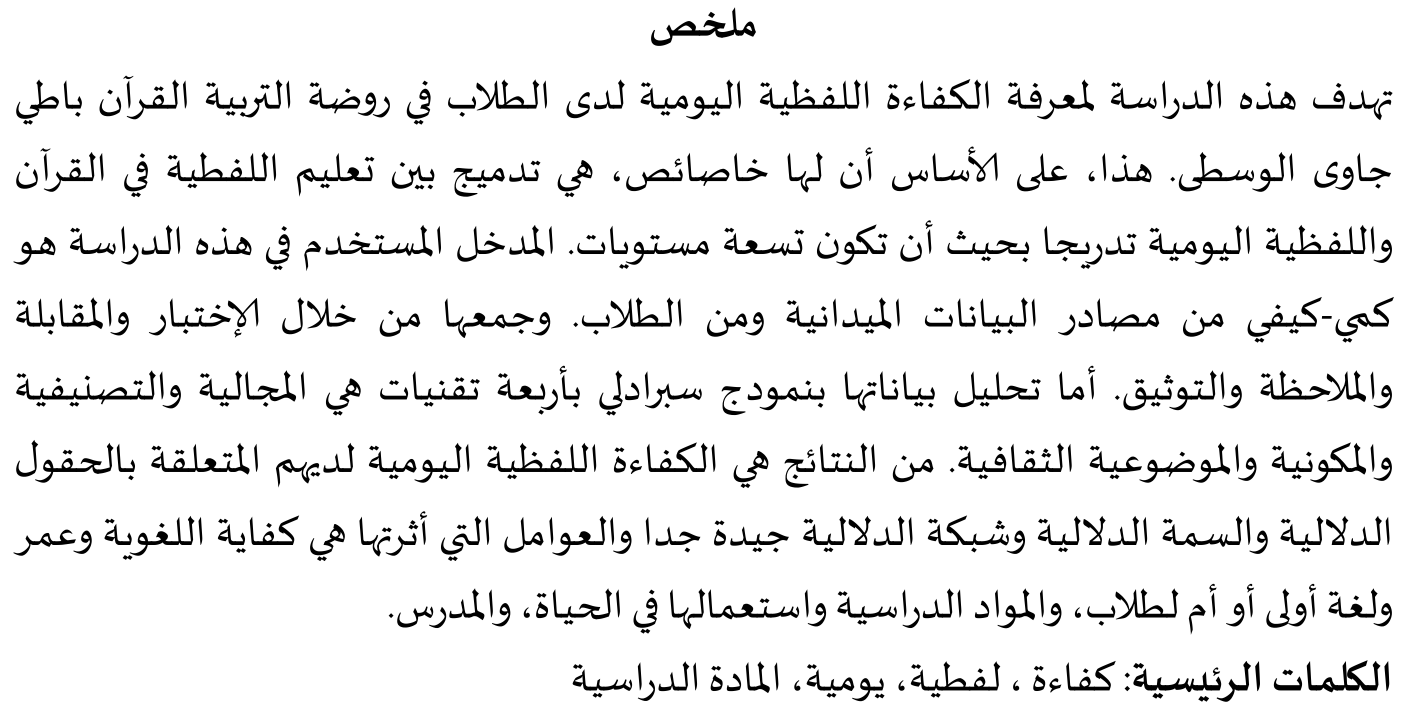

\begin{abstract}
Abstrak
Tulisan ini bertujuan untuk mengetahui penguasaan leksikal keseharian siswa TPQ Nurul Iman Pati Jawa Tengah. Ini berangkat dari keunikan TPQ ini yang memadukan pembelajaran leksikal Alquran dengan kosa kata keseharian secara gradasi menjadi sembilan tingkatan. Pendekatan penelitian ini adalah kuantilatif yang bersumber data dari lapangan dan siswa dengan metode pengumpulan data melalui tes, wawancara, observasi dan dokumentasi. Adapun Analisis datanya menggunakan teknik persentase dan model spradley dengan teknik domain, taksonomi, komponensial dan tema budaya kesimpulan. Hasil penelitian menunjukkan bahwa penguasaan mufradat yaumiyyah siswa TPQ dalam bentuk semantik hierarkis, perbandingan fitur, dan spreading activation network sangat baik dan faktor-faktor yang mempengaruhinya adalah kompetensi atau potensi berbahasa, umur, dan bahasa pertama siswa; materi pembelajaran dan penggunaannya dalam dunia nyata; dan pendidik.
\end{abstract}

Kata kunci: penguasaan, leksikal, keseharian, materi pembelajaran.

\title{
A. Pendahuluan
}

Tujuan inti dari pembelajaran bahasa adalah ilmu bahasa (gramatika) dan ketrampilan berbahasa (menyimak, berbicara, membaca, menulis dan menerjemah). Dalam praktiknya, kelima keterampilan tersebut harus ditopang dengan pengetahuan bahasa yang memadai. Di antara pengetahuan bahasa yang harus dimiliki siswa yaitu pengetahuan leksikal atau dalam bahasa Arab disebut lafdh (Razak \& Samah, 2018). Hanya saja, dalam realitasnya, penguasaan leksikal sebagai fondasi awal pembelajaran bahasa Arab kurang maksimal, baik di sekolah maupun perguruan tinggi. 
Pembelajaran kosakata diberikan tanpa memperhatikan apakah pembelajar mampu menguasai dan menggunakannya atau tidak. Umumnya, proses pembelajarannya adalah pendidik memberikan kosakata yang bervariasi berserta terjemahnya dengan model medan makna atau tematik kepada pembelajar. Setelah pembelajaran selesai, dari pendidik tidak ada tindak lanjut dari penggunaan kosa kata itu. Hal ini berulang-ulang setiap kali pembelajaran bahasa Arab. Maka menjadi lumrah, manakala banyak pembelajar yang lupa leksikal-leksikal yang sudah diajarkan. Ini bisa diidentifikasi dari mayoritas pembelajar yang membuka kamus untuk mengetahui arti suatu leksikal, meski leksikal itu sudah diberikan di pembelajaran sebelumnya (Ali, 2008).

Hal tersebut juga diamini Wahab. Menurutnya, pembelajaran leksikal kurang mendapatkan perhatian karena leksikal sering diposisikan inheren dalam pembelajaran bahasa Arab secara umum tanpa ada kekhususan. Misalnya, ketika belajar qira'ah, pembelajar kurang diorientasikan untuk kemampuan mengeksplorasi dan merevitalisasi kamus, sehingga pengetahuan dan pemahaman pembelajar banyak bergantung pada pendidik. Begitu pula ketika mendapati kosakata baru, pembelajar kurang diarahkan pada kemampuan mengembangkan ungkapan atau kalimat dengan menggunakan leksikal tersebut, sehingga leksikal itu tidak bermakna dan mudah dilupakan (Wahab, 2008). Padahal seperti diungkapkan Tarigan, kualitas, kuantitas, tingkatan dan kedalaman kosakata pembelajar merupakan indeks pribadi yang terbaik bagi perkembangan mental. Selain itu, perkembangan kosakata merupakan perkembangan konseptual, yaitu merupakan suatu tujuan pendidikan dasar bagi setiap sekolah atau perguruan tinggi, di mana pastinya setiap sekolah memiliki tujuan dalam pengembangan sebuah bahasa di lembaganya masing-masing (Tarigan, 1993).

Salah satu lembaga pendidikan dasar yang mengajarkan materi khusus leksikal bahasa Arab adalah Taman Pendidikan Alquran (TPQ) Nurul Iman Mojo Cluwak Pati. Tujuan dari pembelajaran ini adalah selain mampu membaca Alquran dengan baik juga mengetahui makna-makna leksikal di dalamnya. Menariknya, leksikal-leksikal Alquran yang diajarkan dipadukan dengan kosa kata yaumiyyah 
(keseharian) secara gradasi mulai dari kelas jilid satu hingga Alquran yang terdiri dari sembilan tingkatan. Proses pembelajaran ini menggunakan metode gerak dan lagu sehingga memungkinkan pembelajar dapat menghafal leksikal-leksikal itu dengan mudah dan menyenangkan. Meskipun strategi pembelajaran ini sudah berlangsung lama, namun tidak semua pembelajar hafal atau menguasai leksikalleksikal yang diajarkan. Atas dasar ini, tulisan ini akan meneliti bagaimana penguasaan leksikal bahasa Arab materi yaumiyyah siswa TPQ Nurul Iman Mojo Cluwak Pati.

\section{B. Penguasaan Leksikal Yaumiyyah dalam Pembelajaran Bahasa Arab}

\section{Materi Leksikal dalam Pembelajaran Arab}

Pembelajaran merupakan penguasaan atau pemerolehan pengetahuan tentang suatu subjek atau keterampilan dengan belajar, pengalaman, atau instruksi (Brown, 2007). Sebuah pembelajaran akan mencapai tujuan yang ditentukan jika komponen-komponen yang ada dalam pembelajaran terpenuhi. Salah satu komponen yang harus terpenuhi adalah materi pembelajaran atau bahan ajar (almawad ad-dirasiyyah). Materi pembelajaran adalah bahan yang terdiri dari beberapa aspek yang disusun secara sistematis dan dipakai oleh guru dan siswa dalam proses pembelajaran untuk mencapai tujuan tertentu (Hamid, Bahruddin, \& Musthofa, 2008). Secara spesifik, materi pembelajaran bisa diartikan sebagai suatu informasi yang harus diserap pembelajar melalui pembelajaran yang menyenangkan dan memanfaatkan dengan baik setelah mempelajarinya.

Secara umum, materi atau bahan ajar harus memenuhi beberapa kriteria, seperti kerelevanan dengan Kompetensi Inti (KI) dan Kompetensi Dasar (KD), isi pembelajaran dan penjabaran dari KI dan KD, adanya unsur motivasi, disusun secara sistematis, praktis, bermanfaat, up to date, mudah diperoleh, menarik, adanya aspek linguistik yang sesuai dengan kemampuan pembelajar, berkaitan dengan mata pelajaran lainnya, menstimulasi pembelajar, realistis, jelas dan tegas, membedakan sesuai kebutuhan faktor usia, penghargaan keberagaman siswa (Iskandarwassid \& Suendar, 2009). Dengan begitu materi pembelajaran akan mampu mempermudah pembelajar memperoleh pengetahuan bahasa. Secara garis 
besar langkah-langkah pemilihan materi pembelajaran meliputi: (1) mengidentifikasi aspek-aspek yang terdapat dalam KI, KD yang menjadi acuan atau rujukan pemilihan bahan ajar; (2) mengidentifikasi jenis-jenis materi bahan ajar; (3) memilih bahan ajar yang relevan atau sesuai dengan KI dan KD yang telah teridentifikasi, dan (4) memilih sumber bahan ajar (Sumiyadi \& Anshori, 2009). Pemilihan materi pembelajaran yang tepat dan optimal dilakukan dalam rangka membantu pembelajar untuk mencapai tujuan pembelajaran. Selain itu, khusus untuk pembelajaran bahasa arab, materi harus disesuaikan dengan tingkat kemampuan pembelajar, melihat bahasa Arab adalah bahasa kedua untuk orang Indonesia, sehingga dalam penentuan materi perlu untuk dikaji dan ditindak lanjuti secara berulang-ulang agar materi tepat guna dan tingkat penguasaan pembelajar berkembang dengan baik. Untuk tataran pemula materi yang tepat adalah pengenalan leksikal.

Dalam menentukan materi pembelajaran bahasa Arab didasarkan pada dua komponen, yaitu sistem bahasa (kompetensi) dan pemakaian bahasa (ketrampilan). Materi untuk kompetensi (kifayah lugawiyyah) meliputi tataran struktur bahasa itu sendiri yaitu fonologi (vokal dan konsonan), morfologi (leksikal dan kata), sintaksis (kata, frasa, klausa, kalimat dan wacana) dan semantik (makna dari semua tataran bahasa sebelumnya) (Chaer, 2003). Adapun dari segi pemakaian bahasa, bahan ajar bahasa Arab mengacu kepada perwujudan wacana (al-khitab) yaitu keterampilan berbahasa (al-maharat al-lugawiyyah) yang terdiri dari menyimak, berbicara, membaca, menulis dan menerjemah (Luthfi, 2020). Berdasarkan hierarkis komponen materi pembelajaran ini maka leksikal berada di bawah payung morfologi dan diaplikasikan dalam tataran sintaksis dan semantik. Sementara di komponen ketrampilan, maka leksikal masuk di semuanya kemahiran. Ini karena leksikal merupakan fondasi awal, selain vokal dan konsonan dalam berkomunikasi menggunakan bahasa, dan tanpa leksikal, komunikasi akan macet. Dalam konteks ini, leksikal bisa diartikan sebagai semua informasi tentang makna dan pemakaian kata dalam bahasa (Kridalaksana, 2008). 
Leksikal adalah bentuk ejektif yang diturunkan dari bentuk nomina leksikon. Satuan dari leksikon adalah leksem, yaitu bentuk bahasa yang bermakna. Kalau leksikon disamakan dengan kosakata, maka leksem dapat disamakan dengan kata. Dengan itu, leksikal berarti makna yang bersifat leksikon, bersifat leksem atau bersifat kata (Chaer, 2002). Dalam kajian morfologi, leksem diartikan sebagai bentuk dasar setelah mengalami proses morfologis sehingga menjadi kata. Sedangkan dalam kajian semantik, leksem berarti satuan bahasa yang memiliki satu makna atau satu pengertian, seperti "air" dalam arti sejenis barang cair yang digunakan untuk keperluan sehari-hari (Chaer, 2009). Leksikal yang dimaksudkan di sini adalah yang bersangkutan dengan leksem atau kata yang pintu masuknya dari morfologi yang ditinjau dari segi makna. Di mana kata adalah bagian dari morfem bermakna leksikal, yaitu morfem-morfem yang secara inheren telah memiliki makna pada dirinya sendiri, tanpa berproses dengan morfem lain (Chaer, 2003). Dengan demikian, leksikal adalah perbendaharaan kata atau kosa kata, yang disebut mufradat atau lafdh dalam linguistik Arab (Hidayatullah, 2010).

Tarigan memberikan jenis-jenis leksikal yang harus diketahui pada awal pengenalan bahasa asing (baca: Arab) adalah leksikal dasar, yaitu kata-kata yang tidak mudah berubah atau sedikit sekali kemungkinannya dipungut dari bahasa lain. Jenis-jenis leksikal dasar: Istilah kekerabatan, misalnya: Ayah, ibu, anak, kakak, adik, nenek, kakek, paman, bibi dan sejenisnya. Nama-nama bagian tubuh, misalnya: kepala, rambut, mata, dan sejenisnya. Kata ganti pokok (diri, penunjuk), misalnya: saya, kamu, dia, mereka, sini, situ, sana, ini, itu. Kata bilangan pokok, misalnya: satu, dua, tiga, dan seterusnya. Kata kerja pokok, misalnya: makan, minum, tidur, bangun, berdiri, berbicara dan sebagainya. Kata keadaan pokok, misalnya: lapar, haus, kenyang, sakit, bersih, kotor, dan seterusnya. Nama benda-benda universal, misalnya: tanah, air, api, udara, langit, bumi, bintang dan seterusnya (Tarigan, 1993).

Dalam morfologi Arab, leksikal berarti merujuk pada kata dasar yang disebut lafdh (لفظ). Menurut mazhab Basrah, kata dasar adalah fi'l madhi (kata kerja 
lampau), sedangkan menurut mazhab Kufah adalah masdar (infinitif, kata benda). Jika merujuk pada morfologi modern Arab, maka leksikal yang tepat adalah sesuai dengan mazhab Kufah, masdar pada sistem perubahan morfologis pada tingkat pertama. Ini karena, masdar merupakan kata dasar yang belum mendapat imbuhan apa pun dan secara makna tidak terikat waktu atau subjek. Ini berbeda dengan fi'l madhi yang secara semantik, bersifat gramatikal, karena di dalamnya include subjek dari makna dari kata kerja tersebut. Istilah masdar untuk pengertian leksikal ini juga bisa disebut sebagai fi'il tetapi yang sudah "dibendakan". Jadi, selain masdar seperti fi'l madhi, mudharai' dan amr; ism maf'ul, fail dan lain-lainya dalam sistem tasrif dalam bahasa Arab disebut kalimah (كلمة) atau kata, yaitu leksikal yang sudah mengalami proses morfologis.

Selain itu leksem juga bisa merujuk pada kata benda yang tidak bersifat inflektif (tasrif atau musytaq) yang belum mendapat imbuhan apa pun. Umumnya, leksikal ini disebut dengan jamid. Ada juga yang memasukkan kata sambung atau konjugasi (حرف) sebagai leksem. Dari sisi bentuk (syakl), harf memang berdiri sendiri, tetapi dari segi makna tidak bisa bisa. Harf akan memiliki makna manakala disambung dengan kata lain. Ini artinya, harus ada proses baik morfologi maupun gramatikal untuk menjelaskannya. Karena itu, harf sebenarnya tidak masuk dalam pengertian leksikal atau lafdh dalam bahasa Arab, melainkan kalimah.

Di antara contoh-contoh leksikal adalah nama manusia, seperti Ibrahim

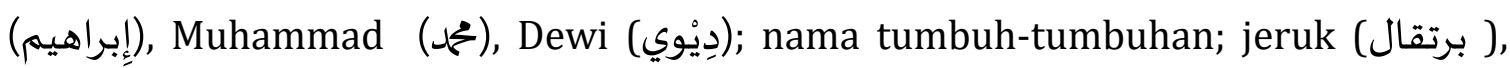

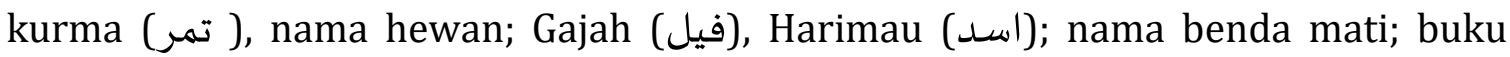
(دفتر), pena (قلم) (حاجين), nama tempat; Kajen Surabaya (سورابايا) ); keterangan waktu; hari ( اليوم), seminggu (أأسبوع); (جميل), keterangan sifat; bagus (كبير);

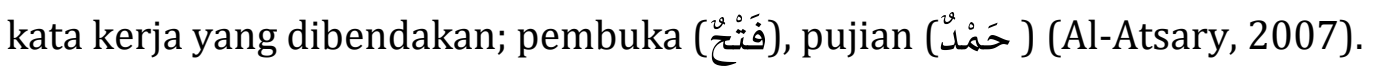

Secara khusus, dalam materi pembelajaran leksikal Arab memiliki beberapa tujuan, yaitu memperkenalkan leksikal baru, melatih agar dapat melafalkan leksikal dengan baik dan benar, memahami makna leksikal saat berdiri sendiri maupun pada 
kalimat, dan mampu mengapresiasi dan memfungsikan leksikal dalam bentuk lisan maupun tulisan sesuai konteks yang benar. Tujuan-tujuan ini mencerminkan integrasi kompetensi kognitif (mengenal, mengetahui, menyebutkan), afektif (mengapresiasi, menilai bermanfaat) dan psikomotorik (melafalkan, menggunakan, memfungsikan) (Wahab, 2008).

\section{Penguasaan Leksikal Yaumiyyah}

Penguasaan dalam Kamus Besar Bahasa Indonesia (KBBI) diartikan sebagai proses, cara atau perbuatan menguasai. Penguasaan juga bisa berarti pemahaman atau kesanggupan untuk menggunakan pengetahuan/kepandaian. Dalam konteks pembelajaran bahasa, istilah penguasaan disamakan dengan istilah kompetensi sebagaimana dicetuskan oleh Noam Chomsky. Dalam teorinya, yang dikenal dengan Innates hypotesis (hipotesis bawaan), menyatakan manusia sejak lahir telah dilengkapi kemampuan bawaan yang khas untuk menciptakan dan memperoleh bahasa. Bagi Chomsky, sejak lahir manusia memiliki perangkat pemerolehan bahasa yang dikenal dengan language acqusition device (LAD). Artinya, anak ketika dilahirkan sudah dibekali potensi alami, yang dalam istilah Tammam Hassan disebut saliqah lugawiyyah (talenta berbahasa sesuai dengan naturnya) (Wahab, 2009). LAD adalah kaidah-kaidah universal secara natural yang menjadi dasar perilaku bahasa manusia, dan kaidah-kaidah itu cukup kaya dan patut dipertimbangkan dalam kecepatan proses pembelajaran bahasa.

Istilah kompetensi, oleh Chomsky dibedakan dengan performansi. Menurutnya, kompetensi adalah kemampuan yang bergerak pada wilayah inheren bahasa yang berhubungan dengan sistem kerja otak atau LAD. Sedangkan performansi adalah kemampuan yang bergerak pada penggunaan aktual bahasa oleh pribadi-pribadi dalam tuturan dan tulisan. Atau lebih mudahnya, performansi adalah ketrampilan berbahasa. Kompetensi, imbuhnya, adalah suatu proses generatif, dan bukan "gudang" yang berisi kata-kata, frase-frase atau kalimatkalimat seperti konsep langue dalam teori linguistik De Saussure. Dalam "secondgeneration transformational grammar" (atau G-2) dijelaskan bahwa kompetensi 
adalah tata bahasa suatu bahasa seorang pribadi yang terinternalisasi. Ini berarti kompetensi merupakan kemampuan seseorang untuk menciptakan dan memahami kalimat-kalimat, termasuk kalimat-kalimat yang tidak pernah didengar sebelumnya. Selain itu penjelasan ini juga mencakup pengetahuan seseorang mengenai apa yang benar-benar kalimat dan yang bukan kalimat suatu bahasa tertentu (Tarigan, 2009). Berdasarkan konsep Chomsky ini, yang dimaksud dengan penguasaan leksikal adalah kemampuan seseorang untuk menciptakan dan memahami leksikal-leksikal dari suatu sistem bahasa yang sudah terinternalisasi sejak lahir.

Secara khusus, Dardjowidjojo ketika menjelaskan penguasaan leksikal, merujuk pada teknik prosedural ketika anak memperoleh leksikal. Teknik prosedural ini menyatakan bahwa pada awalnya dalam mengungkapkan kata atau kalimat anak menggunakan gerakan fisiologis, seperti menangis, tersenyum, dan menggerakkan tangan. Biasanya ucapan yang kali pertama muncul adalah suku terakhir dari sebuah leksikal. Setelah itu, dalam perkembangannya, anak akan mengucapkan satu leksikal secara sempurna. Kemampuan ini, menurutnya tidak bisa diukur berdasarkan umur, melainkan tingkat kesulitan sebuah bahasa. Dengan demikian, setiap anak memiliki kemampuan yang berbeda-beda. Bagi Dardjowidjojo, anak bisa disebut menguasai leksikal jika memenuhi beberapa kriteria, seperti fonetik atau fonem leksikal anak mirip dengan orang dewasa; selalu mempunyai referen yang sama; berprinsip pada kini dan sini yang bergantung pada lingkungan bahasa; kata utama (nomina dan adjektiva) dikuasai terlebih dahulu daripada fungsi, dan nomina dan adjektiva mendahului verba (Dardjowidjodjo, 2008).

Dalam hal penguasaan leksikal, di mana melibatkan fungsi kognitif yang di dalamnya berkembang conceptual system dengan sedemikian rupa, maka otak mampu bekerja atau berpikir secara ilmiah. Atas dasar ini, Dardjowidjojo, menunjukkan bahwa strategi penguasaan leksikal pada anak itu terkait dengan fungsi kognitif melalui organisasi konsep yang terdiri dari tiga model.

Pertama, semantik hierarkis, yaitu mengelompokkan makna leksikal berdasarkan bidang tertentu yang bersifat hierarkis. Misalnya, dalam hierarki 
binatang bisa dibreakdow menjadi beberapa bagian. Yang paling atas adalah "binatang" yang memayungi semua konsep di bawahnya. Jadi, "ikan" dan "ayam" termasuk konsep binatang. Begitu juga "ikan" dan "ayam", masing-masing memayungi di bawahnya. Hubungan antara satu konsep dengan konsep langsung ini bersifat "adalah" artinya "ikan lele" adalah ikan. Lele adalah ikan, dan ikan adalah binatang. Fitur yang sudah tercantum pada tingkat yang di atas secara otomatis dimiliki oleh tingkat yang di bawahnya (Dardjowidjodjo, 2008). Makin dekat jarak antara satu tingkat konsep dengan tingkat konsep yang lain, makin dekat hubungan kedua konsep tersebut.

Kedua, perbandingan fitur, yaitu konsep penguasaan leksikal yang dinyatakan dalam daftar komponen yang wajib, dan komponen opsional. Kedua macam fitur atau komponen ini kemudian dibandingkan melalui dua tahap. (1) Semua fitur, baik yang wajib maupun yang opsional, dari dua konsep atau lebih itu dibandingkan. (2) Bila kedua konsep itu memiliki kemiripannya terlalu dekat, maka masuk pada tahap kedua, yaitu tahap di mana yang dibandingkan hanya fitur yang wajib saja. Dari perbandingan ini akan muncul perbedaan fitur, yaitu fitur yang ada di satu konsep tetapi tidak ada di konsep yang lain (Dardjowidjodjo, 2008). Misalnya adalah ayah memiliki fitur insan, dewasa, nikah dan pria, sedangkan ibu fiturnya adalah insan, dewasa, kawin dan wanita. Dari fitur-fitur ini tampak bahwa ayah dan ibu memiliki banyak kemiripan fitur. Dari sini belum dapat ditentukan perbedaan antara konsep ayah dan ibu. Baru setelah masuk tahap kedua, yaitu mencari fitur yang wajib saja, terlihat bahwa ayah itu pria sementara ibu wanita.

Ketiga, spreading activation network, yaitu makna dari suatu penguasaan leksikal yang didasarkan pada jaringan kompleks (mirip jaring laba-laba). Makna suatu leksikal dinyatakan dalam hubungan yang saling berkait. Jarak antara satu hubungan dengan hubungan yang lain menunjukkan kedekatan antara satu makna dengan makna yang bersangkutan. Makin dekat jaraknya makin dekat pula maknanya. Model ini tidak berbentuk hierarki tetapi suatu jaringan yang memiliki hubungan yang kompleks antara satu konsep dengan lainnya. Misalnya, konsep bunga tidak hanya terkait dengan mawar dan warna merah, tetapi juga dengan 
ungu, dan bahkan dengan wanita paling cantik di suatu desa. Cara model ini bekerja adalah; bila satu konsep ter-aktifkan maka "aliran listriknya" menyebar ke konsepkonsep lain yang berkaitan. Aliran itu kuat bila jaraknya dekat, dan makin jauh jaraknya makin kecil alirannya (Dardjowidjodjo, 2008). Selain itu organisasi konsep atau makna ini juga menggunakan teknik lain seperti sinonim (persamaan leksikal), antonim (lawan leksikal), polisemi (satu leksikal memiliki banyak makna), homonim (hierarki leksikal), hiponim (ejaan dan ucapan sama, tapi makna berbeda), ambiguitas (makna ganda) dan redundansi (berlebihan dalam berucap) (Chaer, 2003).

Ketiga model organisasi makna atau konsep ini menunjukkan bahwa penguasaan leksikal lebih bergerak pada inheren atau kognitif otak manusia yang didukung oleh seperangkat sistem bahasa. Seperangkat sistem tersebut akan berkembang ketika didukung strategi penguasaan yang baik dan terarah. Salah satunya adalah dengan materi pembelajaran leksikal yang di dalamnya mengikut sertakan teknik organisasi konsep. Materi pembelajaran yang diberikan di sesuaikan dengan organisasi konsep, dengan semantik hierarkis atau disebut pula dengan istilah medan makna; perbandingan fitur; dan spreading activation network dengan menggunakan teknik seperti disebut sebelumnya.

Adapun leksikal al yaumiyyah, jika ditinjau dari keterampilan bahasa, termasuk dalam keterampilan kalam (berbicara), khususnya muhadasah (dialog). Yaumiyyah berasal dari kata yaum-un yang bermakna "hari", kemudian diri $y a^{\prime}$ nisbah yang berarti "keseharian". Jika dikaitkan dengan pembelajaran leksikal berarti materi kosa kata tentang keseharian khususnya kata benda. Adapun materi

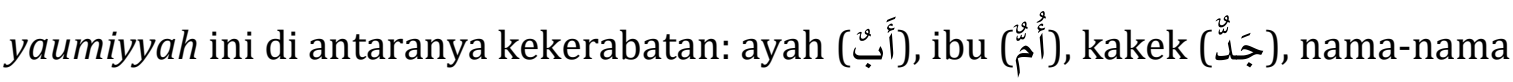

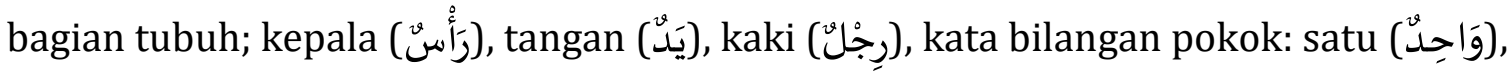

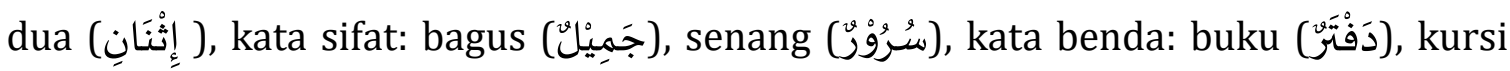

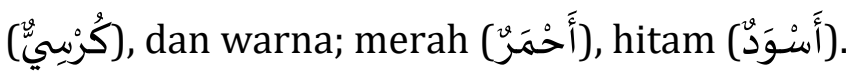




\section{Metode Penelitian}

Pendekatan penelitian ini adalah kuantilatif, yaitu gabungan antara penelitian kuantitatif dan kualitatif. Namun demikian, kuantitatif yang digunakan dalam bentuk sederhana, yaitu persentase. Sementara jenis penelitian ini adalah lapangan (field research) di TPQ Nurul Iman Mojo Cluwak Pati Adapun sifat dari penelitian ini adalah deskriptif-analitik, yaitu menggambarkan secara apa adanya terkait proses Penguasaan Leksikal Bahasa Arab Siswa, serta menganalisis bentuk-bentuk proses penguasaan tersebut dalam pembelajaran sehingga ditemukan faktor penghambat dan pendukung penguasaan leksikal Bahasa Arab dengan didukung persentase angka (Azwar, 2007). Sumber data dalam penelitian ini menggunakan sumber data primer, yaitu siswa yang diambil secara purposive sampling, dan sekunder, yaitu data-data yang mendukung dara primer seperti guru, proses pembelajaran di kelas dan buku ajar TPQ.

Metode pengumpulan datanya adalah observasi dengan partisipasi pasif, wawancara dengan teknik semi terstruktur, dokumentasi dan tes. Adapun kisi-kisi dari tes itu adalah penguasaan hierarkis, semantik fitur, antonim dan antonim. Cara penilaian dari jawaban tes tersebut adalah dengan persentase.

$$
\text { Skor }=\frac{\text { Nilai yang di dapat }}{\text { Skor tertinggi } x \text { item }} \times 100 \%
$$

Data yang terkumpul dikategorikan menjadi; 0-20 (sangat buruk), 21-40 (buruk), 41-60 (sedang), 61-80 (baik), 81-100 (sangat baik). Adapun metode analisis data penelitian ini menggunakan model Spradley, yaitu dengan teknik domain, taksonomi, komponensial dan tema budaya (Bungin, 2008).

\section{Penguasaan Mufradat Yaumiyyah Para Siswa TPQ}

\section{Materi Yaumiyyah TPQ}

TPQ Nurul Iman Mojo berdiri pada tanggal 13 Mei tahun 2001. Visi dari TPQ Nurul Iman Mojo adalah siswa mampu membaca Alquran dengan bacaan tartil sesuai dengan kaidah tajwid, pada batas waktu tertentu siswa sudah mampu khatam 30 juz dan salah satu misinya adalah membekali pembelajar kosakata 
bahasa Arab. Di TPQ ini, bahasa Arab adalah pembelajaran materi tambahan, sedangkan materi pokok adalah Alquran. Khusus bahasa Arab materinya berisi leksikal atau mufradat keseharian siswa. Materi leksikal ini disusun sendiri oleh para pendidik TPQ yang berjumlah sembilan orang. Setiap kelas memiliki materi bahasa Arab yang berbeda, semakin naik tingkatan kelas semakin banyak kosakata yang akan di dapat. Materi bahasa arab di berikan mulai kelas Jilid I-7 hingga kelas Alquran ada 13 tingkatan materi bahasa Arab. Namun khusus kelas juz 27, Alquran, Garib dan Tajwid dijadikan satu kelas, dan kelas akhir (khatimah) sehingga jumlahnya hanya 9 kelas.

Materi leksikal bahasa Arab di TPQ ini diajarkan dengan dua cara. Pertama, materi diberikan ketika proses baris-berbaris sebelum masuk kelas. Penambahan materi pun dilaksanakan pada proses tersebut. Jadi, terkadang siswa mulai mengenal leksikal bukan dari tahap awal, tapi tergantung saat proses tersebut. Kedua, materi disampaikan di kelas setelah diajarkan materi pokok. Materi yang diajarkan di kelas merupakan materi pengulangan atau kelanjutan dari materi saat baris-berbaris. Baik ketika berbaris maupun di kelas materi diajarkan masingmasing sekitar lima sampai sepuluh menit. Jadi setiap pertemuan ada alokasi waktu sekitar 10-20 menit. Metode seperti ini berulang dua sampai tiga kali dalam seminggu. Jadi minimal ada sekitar 30 menit dalam seminggu. Agar menjadi mudah dihafal dan menyenangkan pembelajaran dikemas dengan menggunakan gerak dan lagu atau bernyanyi dengan bahasa Arab beserta artinya yang langsung dipimpin pendidiknya (TIM TPQ Nurul Iman, 2012).

Materi leksikal yang diberikan di TPQ Nurul Iman jenis keseluruhannya adalah berbentuk isim atau kata yang menunjukkan benda. Ketika semua materi ini dikerucutkan pada sebuah tema, maka akan membentuk tema besar yang disebut yaumiyyah. Disebut yaumiyyah karena materi leksikal yang disampaikan pada siswa semua mengacu pada keseharian yang sering dijumpai dan digunakan. Adapun materi leksikal yaumiyyah tersebut, yaitu bilangan, anggota keluarga, anggota badan, nama-nama hari, nama-nama buah, warna-warna, nama-nama hewan, nama benda di sekitar kelas, sifat dan lawannya, ruangan dalam rumah, dan peralatan 
dapur (TIM TPQ Nurul Iman, 2012). Keseluruhan materi tersebut termasuk dari bidang kajian morfologi, khususnya leksem. Ini karena leksikal tersebut termasuk morfem-morfem yang secara inheren telah memiliki makna pada dirinya sendiri tanpa perlu berproses dulu dengan morfem lain, sehingga dapat langsung dipahami tanpa harus mendatangkan kata lain.

\section{Penguasaan Mufradat Yaumiyyah Siswa}

Hasil persentase kemampuan leksikal para pembelajar TPQ berdasarkan teori yang digunakan adalah

Tabel 1. Penguasaan Mufradat Siswa

\begin{tabular}{l|l|l|c}
\hline No. & \multicolumn{1}{|c|}{ Penguasaan Mufradat } & \multicolumn{1}{|c|}{ Persentase } & Rata-rata Persentase \\
\hline 1 & Semantik hierarkis & $95,6 \%$ & \multirow{2}{*}{$81,12 \%$} \\
\hline 2 & Perbandingan semantik fitur & $86,9 \%$ & \\
\hline 3 & Spreading activation network & $60,85 \%$ & \\
\hline
\end{tabular}

Berdasarkan tabel di atas, penguasaan siswa dipetakan menjadi tiga model.

Pertama, Semantik hierarkis. Model medan makna ini membentuk sebuah cabang yang saling berkaitan dari suatu payung besar, di mana siswa dihadapkan pada kata yang saling berhubungan dan membentuk sebuah tema besar, atau sebaliknya dengan siswa dihadapkan sebuah tema besar kemudian diberikan cabang yang berbentuk kata-kata dari pada tema tersebut. sehingga mudah untuk dapat memahami maksud dari kata tersebut. Pembelajaran bahasa Arab model ini banyak ditemukan pada materi leksikal di TPQ (TIM TPQ Nurul Iman, 2012). Ketika Pembelajaran di kelas, saat guru memancing dengan satu kata yang berkaitan dengan model semantik hierarkis ini, siswa dengan mudah dapat menjawab. Hal ini mengindikasikan penguasaan leksikal siswa sangat baik. Ini juga didukung dengan data hasil tes siswa melalui bentuk ini dengan persentase 95,6\%. Dengan didukung materi leksikal yang sebagian besar berbentuk semantik hierarkis atau medan makna, sehingga membentuk sebuah bangunan konsep leksikal pada otak siswa. Maka menjadi hal lumrah manakala siswa cepat tanggap dalam mengaitkan antara satu kata dengan kata lain yang merupakan satu kelompok.

Kedua, perbandingan semantik fitur. Bentuk ini untuk mengetahui siswa mampu menjeniskan dengan benar atau tidak suatu leksikal. Bentuk perbandingan 
fitur dalam pembelajaran di TPQ belum ada. Ini dikarenakan dalam materinya, tidak tersedia bentuk penjenisan leksikal. Penguasaan siswa pada bentuk perbandingan fitur ini adalah dari hasil pemahaman secara spontanitas oleh siswa itu sendiri. Namun demikian, berdasarkan hasil tes, siswa dengan sangat baik mampu menjeniskan pada bentuk golongan tertentu hingga mencapai 86,9\%. Pengetahuan itu terbentuk ketika siswa juga mengetahui gambar visual, arti dan maksud dari penjenisan yang diinginkan.

Ketiga, spreading activation network. Model kemampuan yang lebih dikenal dengan jaring laba-laba ini memiliki beberapa teknik. Adapun teknik yang digunakan dalam instrumen tes ini berupa sinonim dan antonim. (1) Sinonim. Teknik persamaan kata merupakan salah satu cara membantu siswa melihat hubungan antara kata-kata yang memiliki makna sama. Selain itu juga menolong para siswa menggeneralisasikan serta mengklasifikasikan kata-kata. Sinonim memberi kesempatan untuk mengekspresikan gagasan yang sama dalam berbagai cara. Bahasa Arab memiliki banyak kata yang bersinonim, menuntut pemahaman yang benar dalam penggunaannya. Sebab ketika pemilihan kata tidak sesuai konteksnya akan menimbulkan kekacauan makna. Bentuk penguasaan leksikal dengan teknik sinonim dalam pembelajaran di TPQ belum ada. Hasil penguasaan dengan teknik sinonim hanya diambil dari hasil tes siswa. Penguasaan leksikal siswa dengan teknik sinonim menunjukkan kategori sedang, terlihat dari hasil tes dengan persentase yang menunjukkan 47,8\% siswa yang menguasai. Hal ini disebabkan dalam materi tidak ada penyajian berbentuk sinonim, dan guru juga tidak pernah menyampaikan pada siswa tentang bentuk persamaan kata. Persamaan yang dimaksud bukanlah persamaan yang begitu mendalam dalam segi linguistik maupun penjenisan, namun persamaan dalam hal sifat, seperti halnya yang ada pada bahasa Indonesia yaitu leksikal ibu yang disamakan dengan mama. Materi sinonim bisa dipilih pada tataran yang sangat dasar.

(2) Antonim. Teknik ini dapat membantu siswa mempelajari konsep lawan kata. Di TPQ, materi leksikal berbentuk antonim hanya ada satu, yaitu berada pada jenjang kelas Jilid V. Ada sekitar 18 pasang kata sifat dan lawannya yang diajarkan. 
Pembelajaran dengan bentuk antonim ini, siswa terlihat sangat antusias, hanya saja keantusiasan siswa tidak didukung dengan gambar atau media lain yang membuat siswa dengan mudah memahami. Jawaban siswa sering terbolak-balik ketika ditanya guru. Namun pemahaman siswa dapat dikategorikan cukup baik, ini juga dapat dilihat dari hasil tes siswa yang menunjukkan 73,9 \% siswa telah mampu menjawab dengan benar. Dengan penggabungan antara teknik sinonim dan antonim ini maka penguasaan siswa di model jaring laba-laba ini dibilang baik, yaitu 60,85 $\%$.

Dari ketiga bentuk di atas diketahui bahwa bentuk leksikal yang banyak dikuasai siswa adalah semantik hierarkis. Bentuk perbandingan fitur siswa juga cenderung baik, meskipun dalam materi pembelajaran siswa belum pernah diajarkan. Hal ini sebenarnya menjadikan peluang untuk mengembangkan pembelajaran bahasa Arab. Bentuk sinonim dan antonim hasilnya kurang baik, hanya ketika pada tataran sinonim perlu adanya perbaikan-perbaikan dan pengembangan dalam materi bahasa Arab, agar siswa mampu mengerti persamaan kata dalam bahasa Arab. Dalam bentuk antonim juga masih perlu perbaikanperbaikan dalam pembelajaran. Namun demikian, secara keseluruhan, penguasaan leksikal siswa terbilang sangat baik, yakni 81,12 \%.

\section{Analisis Kritis Penguasaan Mufradat}

Dilihat secara umum, penelitian ini menunjukkan hasil yang sangat baik terkait penguasaan leksikal siswa. Yang menarik dari hasil ini adalah metode yang digunakan untuk mengajar siswa tidak variatif, hanya mengandalkan metode bernyanyi. Ini jelas bertentangan dengan teori umum yang mengatakan agar siswa tidak jenuh dan bosan, pendidik perlu menggunakan berbagai metode (Andriyani \& Nurmalina, 2020). Selain itu, motivasi belajar bahasa Arab dari siswa dan pendidik rendah. Pembelajaran di TPQ lebih diarahkan pada kemampuan membaca Alquran. Ini karena siswa dan pendidik, belum merasa membutuhkan leksikal Arab dalam kehidupan sehari-hari, kecuali ingin mengetahui makna dari doa-doa yang sudah diajarkan. Meski demikian, dengan cara mengulang-ulang dengan leksikal yang didapat di setiap pembelajaran, siswa justru semakin hafal. Peristiwa ini sejalan 
dengan teori behaviorisme bahwa pembiasaan merupakan metode ampuh dalam pembelajaran dan lingkungan adalah penyedia data utama. Dengan bahasa lain, kemampuan leksikal anak tidak dipengaruhi faktor internal (baca: motivasi) melainkan eksternal.

Argumentasi di atas juga diperkuat dengan penguasaan yang rendah di model spreading activation network, terutama di sinonim. Pada kasus ini, karena di dalam buku materi tidak ada sinonimitas maka guru tidak mengajarkannya kepada siswa. Ternyata, ketika siswa disuruh mencari persamaan kata, خال (paman) banyak yang tidak bisa menjawab. Penemuan ini bertentangan dengan pendapat Chomsky yang beraliran nativisme yang mengatakan kemampuan berbahasa, dalam hal ini leksikal, bersifat innate yang ada sejak lahir. Namun demikian, bila yang dilihat adalah hasil dari model semantik fitur yang sangat baik, tulisan ini memperkuat teori nativisme. Ini karena, siswa mampu menggunakan potensi bahasanya untuk mengenali fitur-fitur makna leksikal yaumiyyah. Padahal, dalam praktik pembelajaran, pendidik belum pernah mengajarkannya.

Adanya dua pertentangan data ini menunjukkan bahwa antara potensi bawaan dan lingkungan saling bekerja sama. Tergantung dari kognisi siswa untuk memahami dan menghayatinya. Bila disimpulkan, hasil ini lebih dekat dengan teori kontruksivisme. Artinya, potensi berbahasa jika tidak dimaksimalkan dan mendapat asupan dari dunia luar akan mandeg. Demikian juga, data bahasa yang masuk dari luar tidak akan berpengaruh, kecuali siswa mengolahnya baik melalui potensi bawaan maupun kognisi yang dimiliki. Kognisi ini pun tidak akan berjalan dengan baik manakala keadaan psikologi siswa tidak nyaman. Dalam hal ini, penggunaan lagu-lagu untuk bernyanyi sehingga siswa menjadi rileks, senang, terhibur dan nyaman (tidak) tertekan juga ikut mempengaruhi penguasaan leksikal (Slamet, 2020). Yang terakhir ini lebih dekat dengan teori humanisme.

Hal lain yang mempengaruhi keberhasilan penguasaan leksikal adalah usia siswa berkisar antara 6 sampai 13 tahun. Usia ini adalah usia emas seseorang dalam kemudahan pemerolehan bahasa kedua. Berbagai hasil penelitian, perbedaan umur 
mempengaruhi kecepatan dan keberhasilan belajar bahasa dalam aspek fonologi, morfologi dan sintaksis (Markus, Kusmiyati, \& Sucipto, 2017). Maka tak mengherankan apabila penguasaan leksikal anak sangat baik. Hanya saja, yang menjadi catatan, dalam tulisan ini yang diujikan adalah leksikal yang terbatas kata benda keseharian. Hasil akan berbeda manakala yang diujikan adalah kata (leksikal yang sudah mengalami proses morfologis) yang di dalamnya juga menyangkut kata kerja yang bersifat kompleks. Selain itu, penguasaan yang dimaksud dalam penelitian ini lebih condong ke hafalan, yaitu sekedar mengingat makna suatu leksem dan mengaitkannya dengan kata lain (Firdaus \& Hafidah, 2020). Jadi, belum sampai pada tataran cara menggunakan kosa kata itu dalam berbahasa nyata (Hashim, Bakar, \& Ahmad, 2020).

Sementara khusus bahasa pertama atau bahasa ibu siswa, yakni Jawa dan Indonesia, dalam penguasaan leksikal sangat membantu siswa. Ketika guru memancing siswa dengan satu leksikal yang berbentuk medan makna, maka yang keluar pertama kali dari siswa adalah leksikal dengan bentuk bahasa ibu. Misalnya, saat ditanya, siapa saja yang ada di rumah? siswa secara serentak dengan jawaban yang berbeda akan menjawab, ayah (bapak), ibu (mama), adik (adek), kakak (mas). Kemudian siswa menerjemahkannya ke dalam bahasa Arab. أخ dan أب، أم، Untuk kasus leksikal tidak ada masalah. Namun akan berbeda, manakala dalam tataran morfologis atau sintaksis. Karena, antara bahasa Arab dan Indonesia atau Jawa memiliki perbedaan struktur, yang bisa jadi, justru akan mengakibatkan interferensi (pengaruh) dari bahasa ibu ke bahasa Arab.

Berdasarkan analisis ini, penguasaan leksikal dipengaruhi beberapa faktor, seperti kompetensi atau potensi berbahasa, umur, dan bahasa pertama siswa; kedalaman materi pembelajaran dan penggunaannya dalam dunia nyata; dan pendidik. Untuk faktor yang terakhir ini, ternyata tidak ada satu pun dari pendidik TPQ yang secara formal berlatar belakang pendidikan bahasa Arab. Para pendidik merupakan lulusan madrasah Aliyah. Artinya, secara materi para pendidikan ini 
menguasai bahasa Arab, karena di madrasah memperoleh pelajaran bahasa Arab. Sementara strategi pembelajarannya mereka peroleh secara otodidak berdasarkan pengalaman mengajar yang sudah berjalan bertahun-tahun, bukan strategi yang dari berbagai referensi yang dikaitkan dengan tingkat kemampuan siswa seperti mubtadi', mutawassit dan mutaqadiim (Ramadani \& Baroroh, 2020). Atas dasar ini pula, alasan metode yang digunakan di TPQ kurang bervariatif, karena kurangnya pengetahuan guru mengenai itu. Khusus terkait metode ini, tulisan ini berbeda dengan penelitian sebelumnya yang menunjukkan bahwa metode pembelajaran berpengaruh terhadap penguasaan leksikal siswa, tetapi kurang siginifikan (Nurlaila, 2020)

\section{E. Kesimpulan}

Kajian di atas menunjukkan bahwa penguasaan leksikal yaumiyyah siswa TPQ Nurul Iman Pati dengan model semantik hierarkis, perbandingan fitur, dan spreading activation network khususnya sinonim dan antonim sangat baik dengan persentase $81.12 \%$. Kemampuan leksikal ini, didapat oleh siswa tidak hanya dari materi pembelajaran, melainkan di antara, diperoleh secara mandiri berdasarkan perkembangan kognisi siswa. Namun demikian, ini merupakan hasil dari penguasaan leksikal, belum pada tataran aplikasi leksikal tersebut dalam komunikasi nyata misalnya berdialog antar siswa. Bahkan ada kecenderungan penguasaan leksikal ini hanya hafalan. Untuk itu, perlu kiranya penelitian lanjutan untuk menganalisis dari penggunaan leksikal yaumiyyah ini. 


\section{Daftar Pustaka}

Al-Atsary, A. H. (2007). Pengantar Mudah Belajar Bahasa Arab. Bandung: Pustaka Adhwa.

Ali, M. (2008). Pembentukan Kemampuan Berbahasa Arab Pada Anak Usia Prasekolah Di TPQ Nur Iman Karangjambu Purwanegara Purwokerto Utara, Skripsi Program Studi Pendidikan Bahasa Arab Jurusan Tarbiyah. Purwokerto: STAIN Purwokerto.

Andriyani, R., \& Nurmalina, N. (2020). Pengaruh Metode Bererita terhadap Kemampuan Kosakata Anak Usia 5-6 Tahun di Tk Darussalam Kualu Nenas. Journal on Teacher Education, 1(2), 39-46. Retrieved from journal.universitaspahlawan.ac.id

Azwar, S. (2007). Metode Penelitian. Yogyakarta: Pustaka Pelajar.

Brown, H. D. (2007). Prinsip Pembelajaran dan Pengajaran Bahasa Edisi Kelima. Jakarta: Kedutaan Besar Amerika Serikat.

Bungin, B. (2008). Penelitian Kualitatif, Komunikasi, Ekonomi, Kebijakan Publik dan Ilmu Sosial lainnya. Jakarta: Kencana Prenada Media Group.

Chaer, A. (2002). Pengantar Semantik Bahasa Indonesia. Jakarta: Rineka Cipta. (2003). Linguistik Umum. Jakarta: Rineka Cipta.

Dardjowidjodjo, S. (2008). Psikolinguistik: Pengantar Pemahaman Bahasa Manusia. Jakarta: Yayasan Obor Indonesia.

Firdaus, S., \& Hafidah, S. (2020). Memonik: Solusi Kreatif untuk Meningkatkan Kemampuan Menghafal Kosa Kata Bahasa Arab Siswi Madrasah Aliyah Nurul Jadid. PALAPA, 8(1), 81-96. doi:10.36088/palapa.v8i1.700

Hamid, A., Bahruddin, U., \& Musthofa, B. (2008). Pembelajaran Bahasa Arab, Pendekatan, Metode, Strategi dan Media. Malang: UIN Malang Press.

Hashim, H., Bakar, K. A., \& Ahmad, M. (2020). Penguasaan Kosa Kata Bahasa Arab Menerusi Pengetahuan Makna dan Penggunaannya (Mastery of Arabic Vocabulary Through Knowledge of Meaning and Its Use). MALIM: JURNAL PENGAJIAN UMUM ASIA TENGGARA (SEA Journal of General Studies), 21(0). Retrieved from ejournal.ukm.my

Hidayatullah, Moch. S. (2010). Pengantar Linguistik Bahasa Arab: Klasik Modern. Jakarta: Lembaga Penelitian UIN Syarif Hidayatullah. 
Iskandarwassid, \& Suendar, D. (2009). Strategi Pembelajaran Bahasa. Bandung: Remaja Rosdakarya.

Kridalaksana, H. (2008). Kamus Linguistik. Jakarta: PT Gramedia Pustaka Utama.

Luthfi, K. M. (2020). Epistemologi Nahwu (Pedagogis) Modern. Yogyakarta: Zahir Publishing.

Markus, N., Kusmiyati, K., \& Sucipto, S. (2017). Penguasaan Kosakata Bahasa Indonesia Anak Usia 4-5 Tahun. Jurnal Ilmiah FONEMA : Jurnal Edukasi Bahasa dan Sastra Indonesia, 4(2). doi:10.25139/fonema.v4i2.762

Nurlaila, M. P. N. (2020). Penggunaan Metode Index Card Match Terhadap Penguasaan Kosakata Bahasa Arab. AL-AF'IDAH: Jurnal Pendidikan Bahasa Arab Dan Pengajarannya, 4(1), 51-65. doi:10.52266/al-afidah.v4i1.497

Ramadani, S. F., \& Baroroh, R. U. (2020). Strategies and Methods Of Learning Arabic Vocabulary/ Strategi Dan Metode Pembelajaran Kosakata Bahasa Arab. Ijaz Arabi Journal of Arabic Learning, 3(2). doi:10.18860/ijazarabi.v3i2.10062

Razak, Z. R. A., \& Samah, R. (2018). Saiz Kosa Kata Bahasa Arab dalam kalangan Pelajar di Peringkat Pengajian Tinggi: Permasalahan dan Strategi Pengajaran. International Journal of Language Education and Applied Linguistics, 61-70. doi:10.15282/ijleal.v8.394

Slamet, S. (2020). Penggunaan Metode Bernyanyi Dalam Pembelajaran Mufrodat Bahasa Arab Kelas 7 MTS Ma'arif Suka Slamet Indramayu. Syntax Idea, 2(11), 953-961. doi:10.36418/syntax-idea.v2i11.731

Sumiyadi, \& Anshori, D. S. (2009). Bahasa dan Sastra dalam Perspektif Pendidikan. Bandung: Jurusan Pendidikan Bahasa dan Sastra Indonesia FPBS UPI.

Tarigan, H. G. (1993). Pengajaran Kosakata. Bandung: Angkasa. . (2009). Pengajaran Kompetensi Bahasa. Bandung: Angkasa.

TIM TPQ Nurul Iman. (2012). Materi Bahasa Arab. TPQ Cluwak Pati.

Wahab, M. A. (2008). Epistemologi dan Metodologi Pembelajaran Bahasa Arab. Jakarta: Lembaga Penelitian Universitas Islam Negeri Syarif Hidayatullah. 
(2009). Pemikiran Linguistik Tammam Hassan dalam Pembelajaran Bahasa Arab. Jakarta: Lembaga Penelitian UIN Syarif Hidayatullah. 